\title{
Life Cycle Assessment of the Mixed Municipal Waste Management System Based on Mechanical-Biological Treatment
}

\author{
Karolina Kossakowska ${ }^{1 *}$, Katarzyna Grzesik' \\ 1 Department of Environmental Management and Protection, Faculty of Mining Surveying and Environmental \\ Engineering, AGH University of Science and Technology, al. A. Mickiewicza 30, 30-059 Krakow, Poland \\ * Corresponding author's e-mail: kossakowska@agh.edu.pl
}

\begin{abstract}
The aim of this study was to identify and assess the potential environmental impacts caused by mixed municipal solid waste management system based on mechanical-biological treatment technology in Rybnik, Poland. The study is based on life cycle assessment methodology, with application of EASETECH model. The system elements that were taken under consideration are the collection and transportation of MSW (municipal solid waste); MBT plant (mechanical and biological treatment), transportation between system elements, landfilling with LFG (landfill gas) collection system and gas combustion in flare. The adopted functional unit is $1 \mathrm{Mg}$ of mixed municipal waste generated in Rybnk.
\end{abstract}

Keywords: life cycle assessment, waste management, mechanical-biological treatment, municipal solid waste, waste streams treatment

\section{INTRODUCTION}

The European Union makes great effort to implement the rules of sustainable development. One of the EU objectives is to establish an effective and efficient strategy of waste management in order to reduce the amount of waste generated and enhance the reuse to satisfy the society needs. In order to initiate positive changes a number of obligations, postulates and policies were set up. The basic principle of sustainable development regarding waste management is the waste hierarchy: preventing generation, preparation for reuse, recycling or other recovery, finally disposal of waste, which cannot be recovered. Fulfilling the aims set up by European Commission [European Commision, 1999, 2008] and accordingly by Polish government, such as reduction of amount of biodegradable waste landfilled, increasing the quantity of recovered waste, requires reviewing and adjusting the strategies and systems of solid waste management.

In Poland, there are currently several waste incineration plants operating or being under construction. Therefore, other methods of waste treatment have to be applied for waste management systems in order to meet law requirements. The applicable alternative is mechanicalbiological treatment.

The MBT technology combines both mechanical and biological processes. The main goal of this technology is to reduce the amount of waste directed to landfilling. What is more, it is useful for separation of secondary raw materials and producing refuse derived fuel (RDF). Biological treatment allows stabilizing organic fraction; therefore, obtaining more neutral quality of waste the disposal of which cannot be avoided [Bilitewski et al., 2003, Bilitewski et al., 2010, Siemiątkowski et al. 2014]. Therefore processing waste in MBT plants might be a mean to achieve Directive 1999/31/EC targets regarding disposal of biodegradable waste.

Life cycle assessment (LCA) methodology used to evaluate waste management systems is considered as an expedient tool supporting decisive processes, providing complex and comprehensive analysis of environment impacts [Guinée 
et al., 2002]. It allows investigating and comparing different scenarios, identifying the problems and threats, finally creating a model of planned improvements and their potential positive influence on the environment [Bjarnadottir et al. 2002, den Boer and Cholewa, 2009, Kulczycka and Pietrzyk-Sokulska, 2009].

The LCA technique is commonly used for assessment of environmental impacts of municipal waste treatment systems, plants, scenarios [Blengini, 2008, Guereca et al., 2006, Luoranen et al., 2009, Yang et al., 2014].

A few examples of LCA studies focused on MBT installations were found in the literature. In 2013, Montejo conducted and compared Life Cycle Assessments for $8 \mathrm{MBT}$ plants [Montejo et al, 2013]. According to this study, environmental performance is strongly connected with energy and materials recovery efficiency. The LCA technology was applied to assess the environmental impact of MBP installation in Kraków, Poland [Grzesik and Malinowski, 2016]. The results of this study suggest that aerobic biological treatment has the largest contribution in the general negative impact of the operating plant. The environmental impact of an MBT plant located in Athens was assessed [Abeliotis et al., 2012]. According to this paper complete utilization of outputs (compost, RDF, metals) is the most beneficial operating scenario. A mechanical-biological treatment technology was taken into account in study by Papageorgiou [Papageorgiou et al., 2009]. The conclusion of the analysis is that the existence of end market for output - RDF - is crucial regarding the greenhouse gas emissions of the analysed scenarios. The Spanish case study was included in the study by Bovea [Bovea et al., 2010]. The technology consisting of biogasification of organic matter, material recovery and landfilling with energy recovery system is considered to be the most profitable regarding environmental performance in all impact categories in this case. De Feo analysed several waste management systems, MBT plant was one of scenarios [De Feo and Malvano, 2009]. It was reported that the local, actual plant efficiency taken into account may affect the LCA results.

It is worth noticing that the papers which focus on the mechanical-biological treatment plants modelling including the application of EASETECH model are rare. What is more, only a few works on LCA of municipal waste in Poland in general are published and even fewer regarding life cycle assessment of MBT plants in Poland.

The aim of this work was to calculate the environmental impact resulting from the mixed waste management system operation in 2015 in Rybnik, Poland. The modelling of environmental impact of the MBT plant was performed on real data of the operating installation. Particular outputs, efficiency of the plant were taken into account. The results of this study are useful for quantitative understanding of global environmental impact of MBT technology, as well as the contribution of the impacts caused by unit processes within MBT. The paper is based on LCA methodology and was conducted with a use of EASETECH model an updated version of EASEWASTE an updated version of EASEWASTE model [Kirkeby et al., 2006].

\section{MATERIALS AND METHODS}

\section{Mixed municipal waste characterization}

The input material for the analysed system is mixed municipal waste collected in Rybnik. The city is located in Silesian Voivodship, southwestern Poland. It is inhabited by circa 140 thousands of citizens. The city itself consists of 27 districts with differentiated residence structure. Both large multifamily units and areas of single family housing are present. The Rybnik area is an industrial centre where a few large coal mines, coal processing plants and power plant are located.

No research on municipal waste composition in Rybnik was published recently. Therefore, the waste composition had to be estimated. The average composition of mixed municipal waste in cities inhabited by over 50000 of citizens is given in the National Waste Management Plan 2022 [National Waste Management Plan 2022, 2016]. However, the study is limited to 14 basic material fractions (table 2). More thorough analysis regarding municipal waste composition was conducted by Institute for Ecology of Industrial Areas for Kraków city in 2011 [Sieja et al., 2011]. 11 basic fractions were divided into 34 subfractions, as a result, more detailed composition was obtained (table 1). Ribera conducted an even more detailed analysis, in which the waste was divided into 48 fractions (table 2). Ribera thoroughly examined physical and chemical parameters for each separated waste category [Ribera et al., 2009]. In 
Table 1. Material composition of mixed municipal waste

\begin{tabular}{|c|c|c|c|}
\hline \multicolumn{4}{|c|}{ Waste composition [Sieja, 2011] } \\
\hline \multicolumn{2}{|c|}{ Material fraction contribution [\%] } & \multicolumn{2}{|c|}{ Material fraction contribution [\%] } \\
\hline \multicolumn{2}{|c|}{ Organic waste } & \multicolumn{2}{|c|}{ Textiles } \\
\hline Kitchen, canteen waste & 91.5 & Clothing & 70.3 \\
\hline Garden and park waste & 4.3 & Others & 29.7 \\
\hline Other biodegradable waste & 4.2 & & \\
\hline \multicolumn{2}{|c|}{ Wood } & \multicolumn{2}{|c|}{ Inert } \\
\hline Unprocessed wood & 36 & Soil, rocks & 16.5 \\
\hline Processed wood & 64 & Other & 83.5 \\
\hline \multicolumn{2}{|c|}{ Paper } & \multicolumn{2}{|c|}{ Composites } \\
\hline Glossy Paper/cardboard & 10.4 & Packaging composites & 63.1 \\
\hline Packaging paper/cardboard & 35.3 & Non- Packaging composites & 30.8 \\
\hline Newspapers & 15.2 & Mixed WE-EE & 6 \\
\hline Other paper & 39 & Dan & \\
\hline \multicolumn{2}{|c|}{ Plastics } & Batteries & 3.3 \\
\hline Packaging bags & 18.4 & Other & 96.7 \\
\hline Non - packaging bags & 30.7 & \multicolumn{2}{|c|}{ Metals } \\
\hline Bottles & 21.3 & Packaging ferrous & 57.6 \\
\hline Other packaging & 17.1 & Packaging non-ferrous & 26.9 \\
\hline Other non - packaging & 12.5 & Other ferrous & 13.8 \\
\hline \multicolumn{2}{|c|}{ Glass } & Other non-ferrous & 1.6 \\
\hline Clear packaging & 67.4 & \multicolumn{2}{|c|}{ Other categories } \\
\hline Brown packaging & 14.1 & Diapers & 83.9 \\
\hline Other packaging & 16 & Waste from health care & 2.3 \\
\hline Other non-packaging & 2.5 & Remaining other wastes & 13.9 \\
\hline
\end{tabular}

order to predict the composition of input waste in the system, all the above-mentioned results were combined. The final input waste composition obtained is presented in table 2 .

\section{Mixed municipal waste management system description}

In Rybnik, mixed (residual) municipal waste is collected and transported by dedicated garbage trucks to MBT plants. Besides residual waste, secondary raw materials such as plastics, glass, paper, metals and garden waste are collected separately and sent to recovery. The amount of $50802 \mathrm{Mg}$ of residual waste generated in Rybnik in 2015, was treated in 7 mechanical-biological treatment (MBT) plants. However the major amount of residual waste is treated in MBT plant; therefore this plant is chosen as a representative for the Rybnik city.

Once delivered, the waste is weighted and directed to entry hall, from where it is transported to further phases of treatment by conveyor belts. Firstly, it is delivered to the preliminary manual screening station, where all large objects threatening further processing, such as pieces of furniture, foils, large cardboards, are separated. The remaining waste is directed to a trommel screen, where it is divided into three fractions: 0-80 $\mathrm{mm}$ undersize fraction, $80-200 \mathrm{~mm}$ oversize fraction, and fraction over $200 \mathrm{~mm}$. The fraction over $200 \mathrm{~mm}$ is directed to a manual sorting station, where foils, cardboards, paper are taken out of the waste stream. The $80-200 \mathrm{~mm}$ fraction goes through a magnetic separator, and then it also is directed to the manual sorting station. In this stage, ferrous and non-ferrous metals, plastics, paper and composite packages are separated from the $80-200 \mathrm{~mm}$ fraction of the waste stream. The residues from previous stages are considered as ballast. They are shipped to the landfill. Secondary raw materials sorted out are pressed into cubes, and then sold to be recycled. The undersize $0-80 \mathrm{~mm}$ fraction is directed to a trommel screen dividing the waste stream into two fractions: 0-20 mm - mineral fraction, and 20-80 $\mathrm{mm}-$ bio-waste fraction

The biological treatment is applied to 20-80 mm fraction, which is supposed to contain the largest amount of biodegradable waste. The bio-waste fraction is filled into foil tunnels (bio-reactors) by a line press Green Bagger. 
Table 2. Final input waste composition - mixed municipal waste entering the system

\begin{tabular}{|c|c|c|c|c|}
\hline \multirow{2}{*}{\multicolumn{2}{|c|}{$\begin{array}{c}\text { Waste composition NWMP } \\
{[20]} \\
\text { Material fraction contribution } \\
{[\%][\mathrm{A}]}\end{array}$}} & \multirow[b]{2}{*}{ Material Subfraction [Ribera, 2009] } & \multicolumn{2}{|c|}{ Estimated waste composition in Rybnik } \\
\hline & & & \multirow{2}{*}{$\begin{array}{c}\begin{array}{c}\text { subfraction } \\
\text { contribution } \\
{[\%][\mathrm{B}]}\end{array} \\
75\end{array}$} & \multirow{2}{*}{$\begin{array}{c}\begin{array}{c}\text { final waste } \\
\text { composition }[\%]\left[A^{*} B\right]\end{array} \\
3.15\end{array}$} \\
\hline \multirow{4}{*}{ Fine fraction } & \multirow{4}{*}{4.2} & Ash & & \\
\hline & & Cat litter & 5 & 0.21 \\
\hline & & Cigarette butts & 5 & 0.21 \\
\hline & & Soil & 15 & 0.63 \\
\hline Wood & 2.8 & Wood & 100 & 2.8 \\
\hline \multirow{5}{*}{ Other } & \multirow{5}{*}{3.2} & Diapers, sanitary towels, tampons & 80 & 2.56 \\
\hline & & Cotton, bandages & 3 & 0.096 \\
\hline & & Disposable sanitary products (cloths, gloves) & 2 & 0.064 \\
\hline & & Other combustibles & 12 & 0.384 \\
\hline & & Shoes, leather & 3 & 0.096 \\
\hline \multirow{3}{*}{ Kitchen waste } & \multirow{3}{*}{28.9} & Animal excrements and bedding (straw) & 5 & 1.445 \\
\hline & & Animal food waste & 30 & 8.67 \\
\hline & & Vegetable food waste & 65 & 18.785 \\
\hline \multirow{4}{*}{ Metals } & \multirow{4}{*}{2.6} & Aluminium foil and containers & 8 & 0.208 \\
\hline & & Beverage cans (aluminium) & 20 & 0.52 \\
\hline & & Food cans (tinplate/steel) & 57 & 1.482 \\
\hline & & Other metals & 15 & 0.39 \\
\hline \multirow{3}{*}{ Mineral } & \multirow{3}{*}{3.2} & Other non-combustibles & 63 & 2.016 \\
\hline & & Ceramics & 20 & 0.64 \\
\hline & & Stones, concrete & 17 & 0.544 \\
\hline Dangerous & 0.8 & Batteries & 100 & 0.8 \\
\hline \multirow{11}{*}{ Paper } & \multirow{11}{*}{19.1} & Advertisements & 7 & 1.337 \\
\hline & & Books, phone books & 3 & 0.573 \\
\hline & & Dirty cardboard & 8 & 1.528 \\
\hline & & Dirty paper & 12 & 2.292 \\
\hline & & Kitchen towels & 2 & 0.382 \\
\hline & & Magazines & 3 & 0.573 \\
\hline & & Newsprints & 12 & 2.292 \\
\hline & & Office paper & 6 & 1.146 \\
\hline & & Other clean cardboard & 1 & 1.91 \\
\hline & & Other clean paper & 2 & 0.382 \\
\hline & & Paper and carton containers & 35 & 6.685 \\
\hline \multirow{4}{*}{ Glass } & \multirow{4}{*}{10} & Brown glass & 14 & 1.4 \\
\hline & & Clear glass & 67 & 6.7 \\
\hline & & Green glass & 15 & 1.5 \\
\hline & & Non-recyclable glass & 4 & 0.4 \\
\hline \multirow{2}{*}{ Textiles } & \multirow{2}{*}{2.3} & Textiles & 80 & 1.84 \\
\hline & & Vacuum cleaner bags & 20 & 0.46 \\
\hline \multirow{6}{*}{ Plastics } & & Hard plastic & 20 & 3.02 \\
\hline & & Non-recyclable plastic & 12 & 1.812 \\
\hline & 151 & Plastic bottles & 20 & 3.02 \\
\hline & 15.1 & Plastic products (toys, hangers, pens) & 2 & 0.302 \\
\hline & & Rubber & 1 & 0.151 \\
\hline & & Soft plastic & 45 & 6.795 \\
\hline & & Juice cartons (carton/plastic/aluminium) & 44 & 1.1 \\
\hline Composite & 2.5 & Milk cartons (carton/plastic) & 3 & 0.75 \\
\hline & & Plastic-coated aluminium foil & 26 & 0.65 \\
\hline Yard waste & 5.3 & Yard waste, flowers & 100 & 5.3 \\
\hline
\end{tabular}


Simultaneously, with the filling of tunnels with bio-waste fraction, aeration pipes are installed. The full bioreactor (tunnel, sleeve) is closed with a clip. The process of bio-stabilization is conducted in alternate cycles of ventilation and break. During the first week, when the process is intensive, a ventilation phase lasts 10 minutes and it is followed by a 10 minutes break. During the next 5 weeks, the cycle is modified and aeration is expanded to 20 minutes while a break lasts 40 minutes. The post-processed air is transported into a bio-filter. When the process of biostabilization (biological treatment) is finished, the tunnels are cut open and the stabilized waste is shipped to a landfill.

The landfill is located in close proximity of the MBT plant and it is expected to be working until 2029. It is equipped with a landfill gas capture system and a flare, which is used to combust the produced landfill gas without energy recovery.

\section{The Life Cycle Analysis model for waste management system}

The EASETECH model was employed for the purposes of the study. This model is a further development of the EASEWASTE model. The concept of these both tools is to encompass and evaluate the entire solid waste management system [Damgaard et al., 2014]. On the basis of the introduced data, the EASETECH model calculates the emissions released to environment components: air, soil, water. The consumption of resources and possible avoided emissions are also taken into account. All the accounted exchanges with the environment (emissions released, consumption of resources), are converted into environmental impacts. For that conversion, EASETECH uses various methodologies of life cycle impact assessment (LCIA): EDIP 1997, EDIP2003, IPPC 2007, and the methodologies recommended by the ILCD handbook. EDIP 2003 was developed from previous EDIP 1997 methodology. Comparing to ILCD handbook, it has a wider range of impact categories. In comparison to IPPC 2007, which focuses only on global warming, it offers more complex insight. This study was carried out using the EDIP 2003 method as the impact categories cover potential environmental impacts. The categories of environmental impacts for
EDIP 2003 are: acidification, three kinds of ecotoxicity - acute in water, chronic in soil, chronic in water, eutrophication (separate potentials for $\mathrm{N}$ and $\mathrm{P}$ and combined), terrestrial eutrophication, human toxicity via air, global warming, and photochemical ozone formation impacts on vegetation and on human health, stratospheric ozone depletion [Laurent et al., 2004].

The data research and input into EASTECH model was followed by the calculation of life cycle inventory for particular environmental exchanges - emission of substances, natural resources consumption. The elementary exchanges included in the inventory table contribute to the impact categories. Then, the indicator is calculated for each category. The indicators undergo the process of normalization. As a result normalized environmental impact in Person Equivalent (PE) unit is obtained.

\section{Goal and scope}

The goal of the study was to define the environmental impact of the entire system of municipal solid waste treatment in Rybnik, Poland. The analysed system is based on the mechanical-biological treatment. The individual impacts of particular processes within the system were investigated.

The functional unit of this study is $1 \mathrm{Mg}$ of mixed municipal waste collected in the city. The waste was collected and treated in 2015. The system boundaries established for this research include waste collection and transportation, all processes performed in the mechanical-biological treatment plant, transport of secondary materials and end - waste, and landfilling. The fuel and electricity needed for the defined system and all emissions resulting from waste processing and transportation are taken into account.

Additionally, the boundaries include end waste deposition on landfill site equipped with the basic gas capturing system and leachate collection. The processes such as uncontrolled leachate migration to ground and ground waters, landfill gas oxidation in upper layers of landfill are taken into account. The final processing of raw materials separated in sorting stations is excluded. The system boundaries and materials flow is presented in Figure 1. 


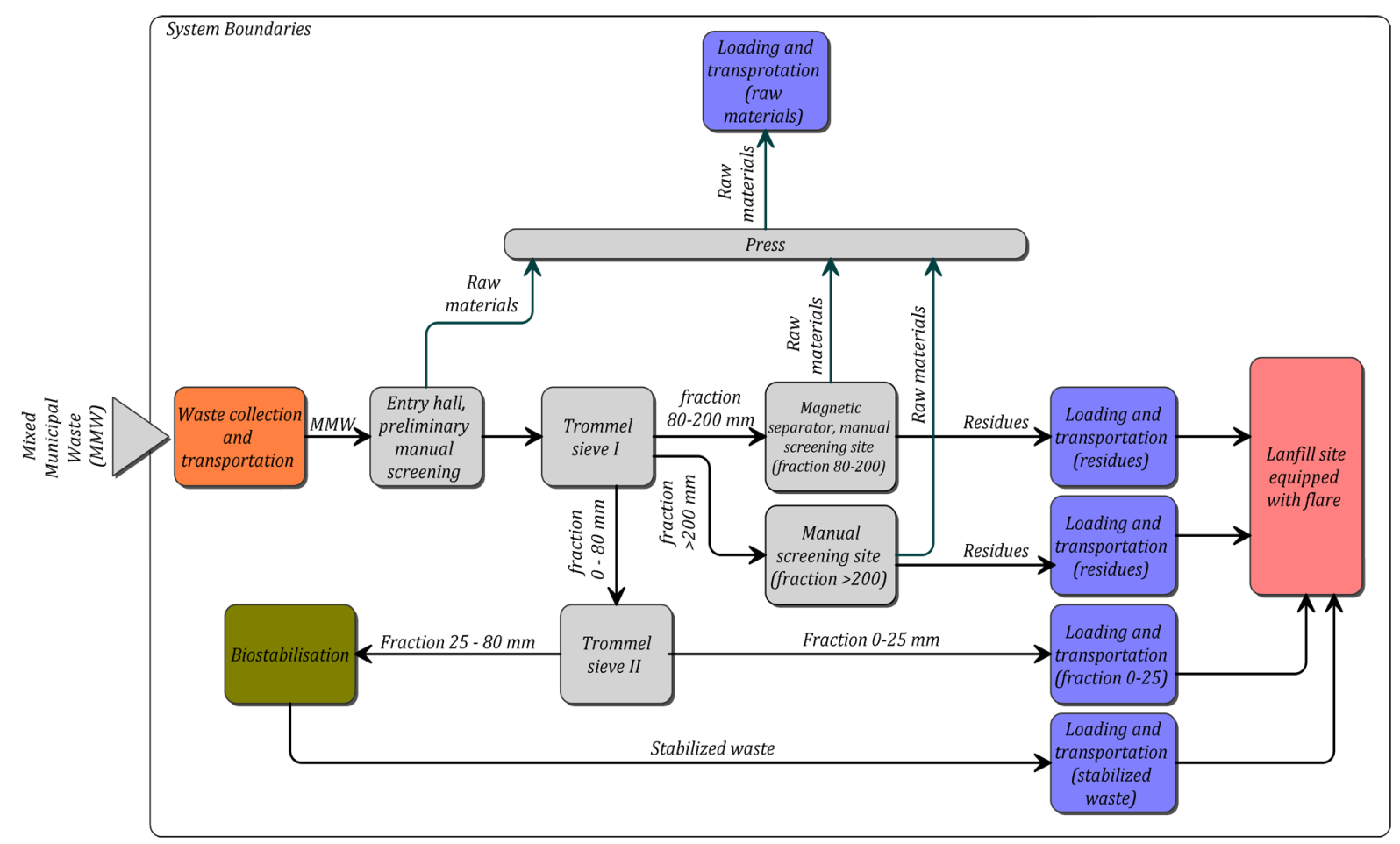

Figure 1. System boundaries

\section{Life Cycle Inventory - input data}

For the purposes of the study, it was necessary to obtain the information about the fuel consumption for waste collection and transportation. The exact data on the amount of fuel combusted by vehicles and quantities of the waste transported in 2015 was shared by the company responsible for waste collection. The average fuel combustion per one kilogram of transported waste was calculated.

The data regarding the operational details of MBT plant such as fuel combustion, working time of devices, nominal and real power of devices, weight of inbound and outbound waste streams was gathered during cooperation with installation in 2014 and 2015. On the basis of the collected data, the energy consumption of each device and fuel consumption of each vehicle operating while MBT is working was assumed. The waste stream flow within installation boundaries including stream division on sieves was assumed on basis of observation of the plant performance.

The process of bio-stabilization of $20-80$ $\mathrm{mm}$ fraction was modelled using degradation of volatile solids (VS), carbon, nitrogen and water for each material fraction.

\section{RESULTS AND DISCUSSION}

The modelling inputs and outputs, mass, waste stream, products and residues flows, electricity and fuel consumption, was followed with LCI calculation for the elementary environmental exchanges within EASETECH model. All emission and substances taken as natural resources contribute to the impact categories. The results of the conducted LCA for mixed municipal waste management system are presented in Figure 2. The significant impact categories are photochemical ozone formation - impact on human health and vegetation, stratospheric ozone depletion, categories connected with eutrophication (N potential, $\mathrm{P}$ potential and combined potential).

The largest influence on photochemical ozone formation was observed for non-fossil methane emission. the amount of $6,542 \mathrm{~kg}$ of methane was introduced to the environment per $1 \mathrm{Mg}$ of processed mixed municipal waste. The main source of this elementary exchange is landfilling of end - wastes produced in the system. Regardless of the fact that the landfill site is equipped with a landfill gases capturing system and a flare, a significant amount of methane is released to the atmosphere as a result of oxidation in the upper layers of landfill during the early stages of 


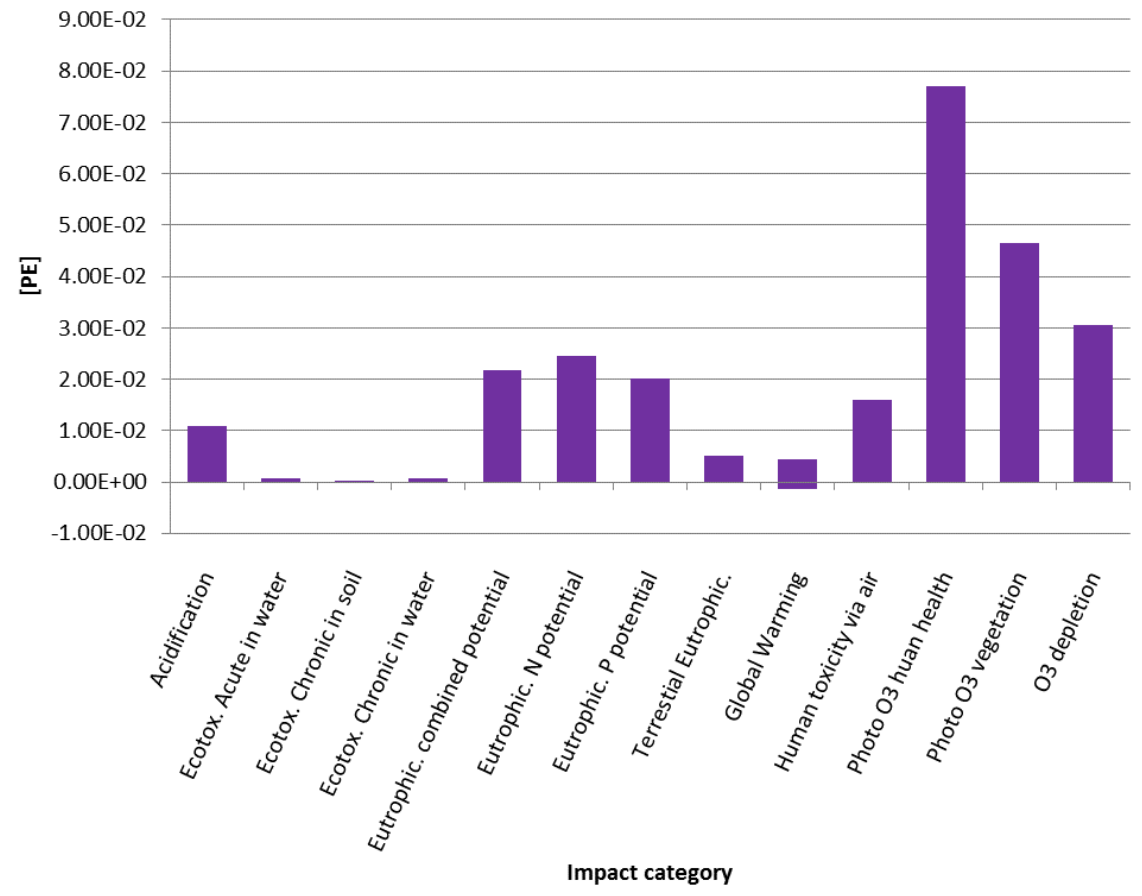

Figure 2. Normalized impact of waste management system (in impact categories)

landfilling. Another emission contributing to high value of the category indicator is the emission of nitrate oxides in the amount of $0.14 \mathrm{~kg}$. The main sources of this emission are connected with gas combustion in the flare and fuel combustion during the landfill construction. For the category stratospheric ozone depletion, the major impact observed is connected with the emission of $\mathrm{xy}$ lene into surface water with amount of $8 \mathrm{mg}$ per $1 \mathrm{Mg}$ of treated waste and selenium into low layers of the urban air with amount of $0.026 \mathrm{mg}$. In both cases, the emissions are connected with fuel combustion during collection and transportation and landfill construction.

Several substances emissions have significant impact on eutrophication $-\mathrm{N}$ potential category. Amongst them, the major impact is observed for nitrates released in the amount of $0.47 \mathrm{~kg}$ per 1 $\mathrm{Mg}$ treated in the system. The entire amount of emitted nitrates originates from the landfilling process, precisely, uncontrolled leachate emission to surface water. Another significant group of substances emitted to the environment is NOx occurring as a result of landfill gas combustion in the flare and fuel consumption during landfill site construction. The appearance of nitrous oxide in amount of $0.06 \mathrm{~kg}$ per functional unit being the product of biological treatment of undersized fraction is also significant. In the case of eutrophication $-\mathrm{P}$ potential, phosphates is the group of substances emitted that influenced the category indicator mostly. They were released into surface waters in the amount of $0.196 \mathrm{~kg}$ per $1 \mathrm{Mg}$ of mixed waste processed as a result of captured landfill wastewater treatment.

Due to the complexity of the system, 5 separate elements of the process were classified: mixed waste collection and transport, mechanical processing, biological processing, loading and transport, landfilling. For the above-mentioned system elements, the aggregated influence on environment was calculated. The greatest influence was observed for the process of landfilling. It is nearly ten times higher than the calculated influence for other elements. The normalized total influence caused by particular system elements is presented in Figure 3.

\section{CONCLUSION}

Regarding the process of landfilling and its high contribution in the entire observed environmental impact, it is desirable to minimize the amount of waste directed to landfill site. Moreover, providing an advanced landfill gas capture and utilization system including CHP (combined heat and power) installation might have a positive effect on the environmental exchanges caused by the system operation. Moreover, the biostabilisation performance is for thorough investigation, starting from the input material quality, through 


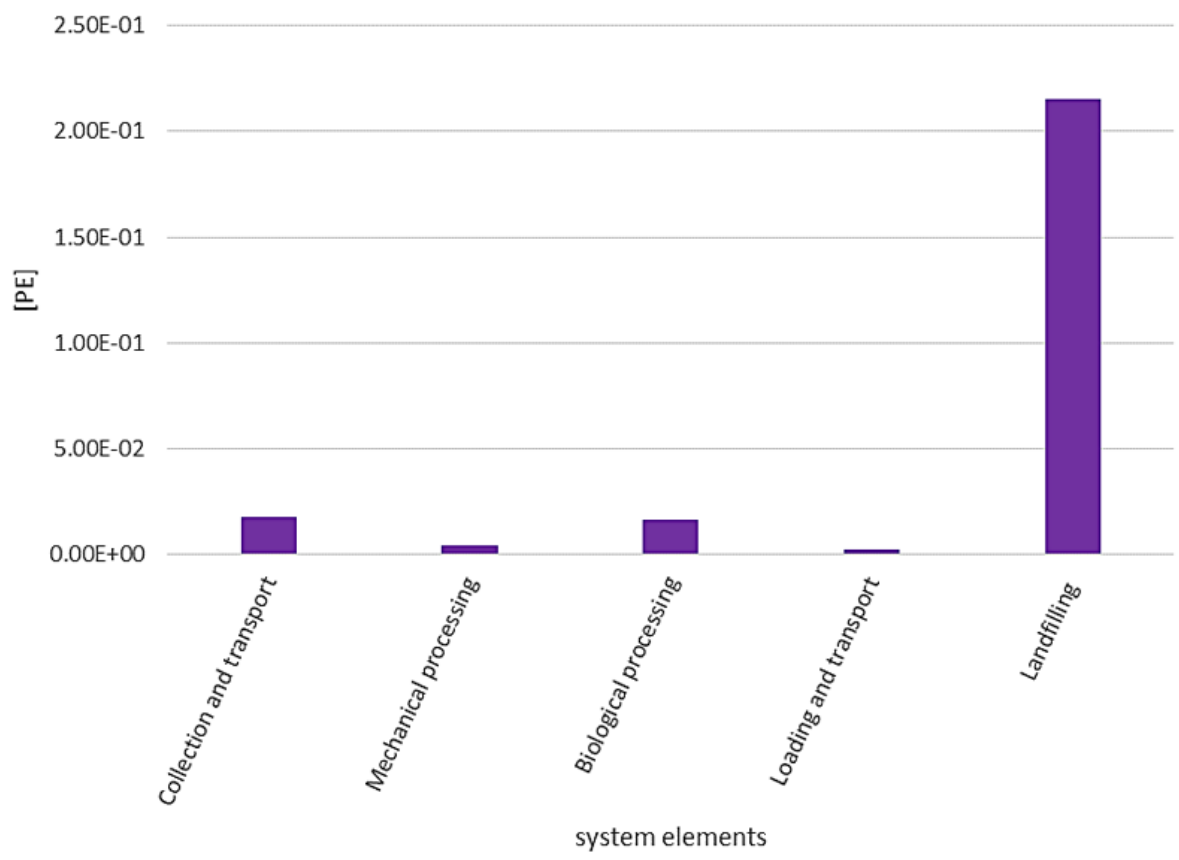

Figure 3. Normalized impact of waste management system per group of processes

operational details of processing (ventilation parameters, processing time), to final stabilized waste features, such as loss of ignition, the content of organic matter, aerobic activity. Additionally, it was noticed that the significant part of ballast remaining after the mechanical processing might be useful for RDF production. This, in turn, should result in a considerable reduction of the amount of waste disposed and affiliated drawbacks.

After implementing the described updates, reviewing input assumption, an alternative scenario might be prepared in order to compare the existing, modelled system with the improved one.

\section{Acknowledgements}

This publication and research was funded by grant no 16.16.150.545. for AGH University of Science and Technology, Faculty of Mining Surveying and Environmental Engineering.

\section{REFERENCES}

1. Abeliotis K., Kalogeropoulos A., Lasaridi K., 2012. Life Cycle Assessment of the MBT plant in Ano Liossia, Athens, Greece. Waste Manage., 32, 213-219.

2. Bilitewski B., Hardtle G., Marek K., 2003. Podręcznik Gospodarki Odpadami - Teoria i praktyka, Wyd.1, Wydawnictwo Seidel - Przywecki Sp. z o.o., Warszawa (in Polish).

3. Bilitewski B., Oros C., Christensen T.H., 2010. Me- chanical Biological Treatment, in: Christensen T.H. (Ed.), Solid Waste Technology \& Management. John Wiley \& Sons Ltd, 628-638.

4. Bjarnadottir H.J., Fridriksson G.B., Johnsen T., 2002. Guidelines for the use of LCA in the waste management sector. Nordtest Report TR 517. Nordtest, Espoo, Finland.

5. Blengini G.A., 2008. Using LCA to evaluate impacts and resources conservation potential of composting. a case study of the Asti district in Italy, Conservation and recycling, 52, 1373-1381.

6. Bovea M.D., Ibáñez-Forés V., Gallardo A., Colomer-Mendoza F.J., 2010. Environmental assessment of alternative municipal solid waste management strategies. A Spanish case study. Waste Manage, 30, 2383-2395.

7. Damgaard A., Baumeister H., Astrup T.F., \& Christensen T.H., 2014. EASETECH - A LCA model for assessment of environmental technologies. In Abstract Book - DTU Sustain Conference, Kgs. Lyngby: Technical University of Denmark.

8. De Feo G., Malvano C., 2009. The use of LCA in selecting the best MSW management system. Waste Manage, 29, 1901-1915.

9. den Boer E., Cholewa M., 2009. Znaczenie LCA w gospodarce odpadami komunalnym w praktyce, Wydawnictwo IGSMiE PAN, Kraków (in Polish).

10. European Commission, 1999. Council Directive 1999/31/EC of 26 April 1999 on the landfill of waste (OJ L 182, 16.7.1999).

11. European Commission, 2008. Directive 2008/98/ EC of the European Parliament and of the Council of 19 November 2008 on waste and repealing cer- 
tain Directives, (OJ L 312, 22.11.2008).

12. Grzesik K., Malinowski M., 2016. Life Cycle Assessment of the Mechanical-Biological Treatment of Mixed Municipal Waste in Miki Recycling, Krakow, Poland, Environmental Engineering Science, September.

13. Guereca L.P., Gasso S., Baldasano J.M., Guerrero P.J., 2006. Life cycle assessment of two biowaste management systems for Barcelona, Spain, Resources, Conservation and Recycling, 49, 32-48,

14. Guinée J.B., Gorrée M., Heijungs R., Huppes G., Kleijn R., Koning A. de, Oers L. van, Wegener Sleeswijk A., Suh, S., Udo de Haes H.A., Bruijn H. de, Duin R. van, Huijbregts M.A.J., 2002. Handbook on life cycle assessment. Operational guide to the ISO standards. I: LCA in perspective. IIa: Guide. IIb: Operational annex. III: Scientific background. Kluwer Academic Publishers, Dordrecht.

15. Kirkeby J.T., Birgisdottir H., Hansen T.L., Christensen T.H., Bhander G.S., Hauschild, M., 2006. Environmental assessment of solid waste systems and technologies: EASEWASTE. Waste Management Research, 24, 3-15.

16. Kulczycka J., Pietrzyk-Sokulska E., 2009. Ewaluacja gospodarki odpadami komunalnymi w Polsce, Wydawnictwo IGSMiE PAN, Kraków (in Polish).

17. Laurent A., Lautier A., Rosenbaum R.K., Olsen, S.I. Hauschild, M.Z., 2011. Normalization in EDIP97 and EDIP2003: updated European inventory for 2004 and guidance towards a consistent use in practice, Int JLCA, 16(8), 728-738.

18. Luoranen M., Soukka R., Denfas G., Horttanainen M., 2009. Comparison of energy and material recovery of household waste management from the environmental point of view - case Kaunasm Lith- uania, Applied Thermal Engineering, 29, 938-944.

19. Montejo C., Tonini D., Márquez M.D.C., Astrup T.F., 2006. Mechanical-biological treatment: Performance and potentials. An LCA of 8 MBT plants including waste characterization. Journal of Environmental Management, 128, 661-673.

20. National Waste Management Plan 2022 (2060). Republic of Poland. Resoluton no. 88 of the Council of Ministers of 1 July 2016 on the National Waste Management Plan 2022, Monitor Polski of 11 August 2016.

21. Papageorgiou A., Karagiannidis A., Barton J.R., and Kalogirou E. 2009. Municipal solid waste management scenarios for Attica and their greenhouse gas emission impact. Waste Management and Research, 27, 928-937.

22. Ribera,C., Petersenb,C., Christensena T.H., 2009. Chemical composition of material fractions in Danish household waste; Waste Management, 29, 1251-1257.

23. Sieja L., Kalisz M., Książek D., Szojda G., Terakowski M., 2011. Badanie ilości i struktury odpadów komunalnych Miasta Krakowa, Instytut Ekologii Terenów Uprzemysłowionych, Katowice (in Polish).

24. Siemiątkowski G., Nolepa A., Binner E., Paciorkowski M., Glanz R., Poluszyńska J., Gąsior J., 2010. Mechaniczno-biologiczne przetwarzanie frakcji biodegradowalnej odpadów komunalnych, Wydawnictwo Instytut Śląski Sp. z o.o., Opole (in Polish).

25. Yang N., Damgaard A., Lü F., Shao L.-M., Brogaard L.K.-S., He P.-J., 2014. Environmental impact assessment on the construction and operation of municipal solid waste sanitary landfills in developing countries: China case study. Waste Manag, 34, 929-937. 